\title{
Amateur Radio Communication Technology Contingency Communication in Emergency Situation
}

\author{
Azlee Johar ${ }^{1, *}$, Wan Rozaini Sheik Osman ${ }^{2}$, and Azizi Ab. Aziz ${ }^{3}$ \\ ${ }^{1,2,3}$ School of Computing, Universiti Utara Malaysia, 06010 UUM Sintok, Kedah, Malaysia
}

\begin{abstract}
Disasters cannot be avoided, but efforts can be made to reduce death, injuries and property damages through better communications and better planning to deal with it before it happen. Thus we need to adopt available technology, like the Amateur Radio Communication Technology (ACT), to face this problem. These include providing awareness, training and support for the communities who adopt the technology for Emergency Communication (EC). Through having more qualified Amateur Radio Communities (ARC) in the adoption of the ARCT, we would be able to improve the communication before, during and after the disasters struck. There are many challenges and issues in the adoption of the ARCT that would part of this study. This article also describes several case studies of communication failure during Hurricane Katrina (2005) in the USA, as well as disasters in several other countries and Malaysia. The tragedies led to failure of existing communication infrastructure, and were reprieved by the help of the voluntary ARC to support the relief agencies in the evacuation and assistance the disaster victims. Therefore, this article will highlight the significant issues that influence the adoption of ARCT in EC.
\end{abstract}

\section{Introduction}

Emergency Communications (EC) may include early warning, command on the evacuation, curfews and other self-protection measures and other matters which influence relief, response and recovery activities [2, 3, 18]. Many disasters led to the breakdown of existing infrastructure, and resulted in the loss of many live and damages to properties [1]. Indeed, a wireless communication technology like Amateur Radio communication Technology (ARCT) as a contingency communication is suitable to facilitate the dissemination and sharing of information among stakeholders and role players. ARCT is important role in restoration in emergencies due to easy to operate and easily accessible simultaneously everyone within the same time in form of radio waves. This fact has been proven in several emergency incidents that have occurred around the world and its role cannot be denied. However, [23, 26, 29] argued that the adoption of ARCT is still having gaps and not widespread use, particularly among developing country.

* Corresponding author: azlee@gmail.com 
As researchers in the field of wireless communications technology it is interesting to see the slogan from the International Amateur Radio Community (IARC), "When all else fails, ham radio works". The slogan belongs to the American Radio Relay League [5]. These statements indicate that ARCT is important and can be a very useful as it works every time when existing communication fails to operate in emergency situation.

The Emergency Situation (ES) could be pre and post of most disasters [15]. That means when every existing communication facilities have been destroyed due to any huge disaster, the contingency communication in ES should be performed. In this situation the role of Amateur Radio Community (ARC) become important in adoption and use of ARCT to support relief agencies. The importance of ARCT as contingency communication has proved during the disasters struck in most country and in Malaysia.

\section{Methodologies}

This article is a qualitative research by reference related books and through studies related journals. The outline and angle of this article is only focus to the adoption the ARCT. The methodology involved casual interview approach to certify usability former to get perfect evidence. Casual interviews with several individual among Amateur Radio Community (ARC) and individuals involved in disaster management and emergency communications are conducted to obtain an issues related to the adoption of ARCT. A casual interview is to realize their perception of the issues at hand also conducted. Some of significance articles and reference books which are related to ARCT were obtained from them.

\section{ARCT contingency communications}

The most apparent and unique feature regarding the adoption of ARCT is the parallel volunteer work by the same ARC during Hurricane Katrina in New Orleans (2005) in USA. ARC provides much information to the relief agencies in rescue missions and evacuation missions. Hurricane Katrina strikes the New Orleans city in USA and cause the failure of the existing communications. An issue is about the failure to prepare an early warning before a disaster strike that caused major loss in lives and properties. This tragedy is a great disaster for a strong government as USA [4, 20, 21].

Communications became an increasingly critical function in the emergency management during that time. The sharing and dissemination information of timely and accurate to the general public, elected and community officials and the media is a most important role in the effective management of disaster response, however, the relief and recovery action was totally lost in New Orleans city after Hurricane Katrina struck. Communications failures by government responders in Hurricane Katrina (2005) were noted in the report prepared by the United States House of Representatives. According to $[6,8,10]$ the president of USA during that time, George W. Bush lamented about the communication failure when Hurricane Katrina struck;

"What happen with communications structure during that time, why coordination and information sharing and dissemination among local, state and federal governments too miserable and why situational awareness was so foggy, for so long and why unsubstantiated rumours and uncritically repeated press reports at times fuelled by top officials were able to delay, disrupt, and diminish the response" .

The failure of existing communications mechanism among local, state and federal governments, relief agencies and community in sharing and dissemination information in ES, due to the violence storm, caused huge community concerns and further delayed relief during Hurricane Katrina in New Orleans that year. Fortunately there was an ARC who volunteered to build a tower and setup the antenna to communicate via ARCT among them and relief agencies to report on conditions that enable further action by the government to assist the victims of the disaster [20]. Thus, the adoption and use of ARCT as the 
contingency communications is effectively used for the EC in the USA after Hurricane Katrina.

Many Malaysians remember the landslide disaster that occurred at the Highlands Tower apartment in Bukit Antarabangsa, Kuala Lumpur in 1999. The incident not only trapped many people as the main road was buried by the loose soil but also claimed the loss of many lives of the Highlands Tower apartment residents. The emergency situation has led the country into panic and confusion caused by the irregular communication [22, 25].

The whole country was in shocked, safety and medical officers were deployed to support and relief for those who were trapped. The main problem that arises is how to coordinate emergency communications among relief agencies at the time due to traffic communications congestion. However, according to [21] disaster management and emergency communication will not execute smoothly without effective communication mechanism. In such instances, common communication system like mobile phones, fix line and wireless communication will not function properly due to traffic congestion.

The ARC is experienced in adopting, using and handling traffic congestion wireless communications devices when required to support. Therefore, the government relief agencies have decided to request volunteers among ARC to support and to coordinate the EC among agencies $[9,22]$.

They were a group of volunteers from ARC, which is known as Malaysian Amateur Radio Emergency Service Society (MARES). They were able and successful to provide contingency communication via ARCT during Highlands Tower tragedy [22]. Thus, when in emergency situation, systems and mechanism communication via ARCT which are adopted and used among ARC are able to play the role.

According to [5] many factors contribute to the common communication lines disrupted, including faulty tower or substation communication station power outages. However, the disorder does not occur among ARC in adoption and use of ARCT, because to them, it's not too difficult to setup and to operate but can be difficult to ordinary people. This is because ARCT is unique hobbies among ARC. The passion and close rapport between the ARC members are hard to define and compare [26, 27].

According to [22] in 1999 MARES were called to support and to coordinate communication between Jabatan Pertahanan Awam Malaysia (JPAM), Polis (PDRM), Department of Civil Aviation (DCA) and the Royal Malaysian Air Force (RMAF) in the forest in Mantin, Negeri Sembilan, due to the Cessna Aircraft crash. ARCT base station and repeater communication tower was setup near the aircraft crash location to support relief agencies. So, [9. 19] argued that the advantages of communicating through ARCT were fully utilized during, search and rescue activities. During the incident, others wireless communications such cell phones do not work due to out of coverage area except ARCT.

In addition, each relief agencies use trunk radio communication which is in different frequency and therefore, communication is limited [9, 17]. Thus, MARES was the network who connected and coordinated the communication order among relief agencies.

Most significantly, the importance of ARCT can be seen at the time of the tsunami in Aceh, Indonesia in year 2004 [30]. Even far away, radio frequency from Aceh to request aid has been received by the MARES in Kuala Lumpur. MARES have answered the emergency call from ARC in Aceh that was supposed to be received by the Indonesian communication and relief team in Medan. As a solution, MARES resend the emergency message to the Indonesian authorities. The issues may be due to terrain of mountains, hills and the weather that has deflected the radio signals to Kuala Lumpur from Aceh, even though the distance to Medan is nearer [22].

Consequently, the contingency communication provided during the ES and the contributions of MARES in Kuala Lumpur, made MARES a mediator to help in sharing and dissemination of information between the ARC in Aceh and the Indonesian authorities 
in Medan. MARES were also involved in the rescue operation for tsunami victims in Aceh by providing ARCT equipment to the affected residents.

However in normal situations, MARES or other ARC are forbidden to intrude authorities' frequency or any 'Air band frequency'. ARC in Malaysia only can use those frequencies with the order and permission of the Malaysia Multimedia and Communication Commission (MCMC) during emergency and in a controlled manner and procedure [24]. This is subjected to the Communications Policy and Acts in order to avoid disruption of communication between the authorities $[28,29]$.

\section{The Significance Contingency Communication}

The adoption and use of ARCT among ARC as contingency communication are very significant. In the world history, the starting point of ARCT as contingency communication in ES was seen from January 31 to February 1, 1953. The combination of high tides and severe weather caused huge flooding in Britain, Holland and Belgium that caused more than 2000 loss of life, crops destroyed and huge facilities damage. In the early time using $\mathrm{ARCT}$ is a unique hobby among ARC in rural area in Britain and Holland. Most members are farmers and fisherman. Nevertheless their hobby has changed to a more important role in the aftermath of the massive tide that struck their countries. This is the beginning point of ARCT work as contingency communication in the world $[7,11,12,18]$.

This leads to the establishment of a group of ARC as contingency communication in ES in their country. Until now, two ARCT stations are active in the UK and Holland as benchmark and to maintain public awareness about the role of ARC in ES [13, 14, 16, 23].

ARC is the key player in the emergency response recorded in Britain and the response leads to official gratitude of ARCT as a source of information sharing and dissemination in emergency situation during any disasters.

According to $[14,25,27]$, in developing countries, ARCT can be the contingency communication among the ARC, stakeholder and public to share and dissemination of information, mostly to use in a rural area and generally in emergency situation.

During the ES in disaster areas, information sharing and dissemination through ARCT is an ideal solution to support and evacuate the victim. Usually, they cannot travel to get the necessary information or use the services, because of lack of transportation, disaster factor, time, or bad weather [3, 27, 29].

It is quite evident that, ARCT services have many benefits such as mobility, ubiquity, ease of use, on-time information delivery, improving emergency management, quick access to role player and stakeholder services and who do not have access to cellular communication and telecommunication services provider. Similarly there are many significant researchers who consider the adoption and use of ARCT in disaster areas as the effective solution to interact with government services, particularly for support and relief team during emergency situations. The most important is the cooperation and contribution of developed countries to underdeveloped countries in providing a framework for effective communication in ES during disaster. Thus ARCT has become a main source of EC in ES during most disaster.

It is obviously that ARCT role as a contingency communication in ES is significance. $[6,8,21]$ stated an effectively EC through contingency communication is to support and to ensure public safety, protect property, facilitate the response, prompt cooperation, public confidence and help families to reunite during any emergency situation. The extent to which community to respond to an EC via contingency communication is influenced by several factor, including individual characteristics and perceptions, whether the message comes from a trustworthiness source, compatibility technology and how the information sharing and dissemination among role player and stakeholders. 


\section{Conclusion}

We have many communication devices to adopt as contingency communication in ES, including in-person events, mass media and broadcast media, internet and social media but the importance thing is to provide trustworthiness information and accurate to generate public safety. Each contingency communication device has advantages and disadvantages depending on the communication impartial and the intended to public. Whatever communication tools to adopt and use is to ensure EC are clear, specific and acceptable information, are synchronise with other information shared and disseminated and to the public during disaster.

Actually the usage of ACRT among ARC are very widespread as only a hobby throughout the world, but their capacity and capability is still less adopted as a contingency communication in ES in most country. Even the military of some country strictly control and gives special emphasis to the communication methods and tactical for special security forces in using ARCT and the public are prohibited from using ARCT.

Lastly, the researchers will propose a study to identify the factors for adoption of ARCT among the ARC in Malaysia in order to highlight their role in ES. Other researchers should also carry out related study on ARCT for the benefits to the stakeholders, the public and the ARC community to cope with ES in the future.

\section{References}

1. A. Majid, M.Sonia, and A. Kazi. Post - disaster communications: A cognitive agent approach. ICN 2008. Seventh International Conference on IEEE, (2008)

2. A.B. Sutiono, H. Suwa and T. Ohta. "Designing an emergency medical information system for the early stages of disasters in developing countries: the human interface advantage, simplicity and efficiency. J MED SYST 34.4, 667-675(2010)

3. A.Qiantori, A.B. Sutiono, H. Hariyanto, H. Suwa and T. Ohta. An emergency medical communications system by low altitude platform at the early stages of a natural disaster in Indonesia. J MED SYST 36.1, 41-52(2012)

4. ADPC. Emergencies Communication during Disasters. Asian Disaster Preparedness Centre. UN World Conference on Disaster Reduction. South Publication, (2013)

5. ARRL. Amateur Radio Emergency Service USA and Canada (ARES). Emergency communication via amateur radio. "when all else fails ham radio works" J.FEMA(2001)

6. C. Coile and C Russell. The role of amateur radio in providing emergency electronic communication for disaster management. Disaster Prevention and Management: An International Journal 6.3: 176-185(1997)

7. D. Kraker and M.J. Adriaan. Flood events in the southwestern Holland and coastal Belgium, 1400-1953. HYDROLOG SCI J. 51.5: 913-929(2006)

8. E. C. Codes. Communicating in an Emergency. Environment of Care ${ }^{\circledR}$ News, 13(7). USA Journal of Federal Emergency Management Agency, (2010)

9. F.A . Ashriq. Radio Amatur Komunikasi Luar Jangka. Kuala Lumpur : Malaysian Amateur Radio Emergency Services (MARES). Utusan Malaysia Publication, (2011)

10. Phillips, D. Brenda D, M. N. David and W. Gary. Introduction to emergency management. CRC Press, (2011)

11. H. Haddow, B. Jane, and P. C. Damon. Introduction to emergency management. Butterworth-Heinemann, (2013)

12. I. Poole, and M. Dennison. Amateur Radio: The First 100 Years: A Photographic History. Potters Bar: Radio Society of Great Britain, (1999) 
13. IARU. Amateur Radio - 60th Anniversary of North Sea Floods. The International Amateur Radio Union Publication, (2013)

14. J.Blackman, K. Colin, and S. Lara . Telecommunications regulation handbook, World Bank Publications, (2011)

15. K. Kovacs, R. Gyongyi, and M. Spens. "Humanitarian logistics in disaster relief operations. Int. J. Phys. Distrib. Logist. Manag. 37.2, 99-114 (2007)

16. L. Benjamin. Working it out together: Radio policy from Hoover to the Radio Act of 1927. J. Broadcast Electron. Media 42.2: 221-236, (1998)

17. L. Lundgren, E. Regina, and A. H. McMakin. Risk communication: A handbook for communicating environmental, safety, and health risks. John Wiley \& Sons, (2013)

18. M. Acharya. Amateur Radio, A potential tool in emergency operations. I Magazine 3.1, (2005)

19. M. Basiron, and N. Fazilah. Pengurusan bencana gempa bumi menurut perspektif AlQuran dan sains moden. Diss. University of Malaya, (2014)

20. M. Burby \& J. Raymond. Hurricane Katrina and the paradoxes of government disaster policy: Bringing about wise governmental decisions for hazardous areas." The Annals of the American Academy of Political and Social Science 604.1:171-191(2006)

21. M. Leonard, T. Michael, S. Graham, and D. Bonacum. The human factor: The critical importance of effective teamwork and communication in providing safe care. Quality and Safety. i85-i90(2004)

22. M. N. Abdul Aziz. Pengenalan kepada Radio Amatur dan Komunikasi Ketika Bencana. Seminar Malaysian Amateur Radio League. Kuala Lumpur: MARL Publication, (2014).

23. M. Scheffe, J. Bascompte, W.A. Brock, V. Brovkin, S.R. Carpenter, Dakos and G. Sugihara. Amateur Radi0 - Early-warning signals for critical transitions, 53-59(2009)

24. M. Abu Hassan. Memanfaatkan teknologi maklumat dan komunikasi (ICT) untuk semua. Universiti Putra Malaysia Press, (2008)

25. MARL. Gabungan Persatuan Radio Amatur Malaysia. Vol. 4. Sekudai Johor : Malaysian Amateur Radio League, (2014)

26. P.E. Jacobsmeyer. Amateur Radio Often overlooked, but vitally important. Extremely important communications, especially during and after emergencies. IWCE's. J. W.Commun. IEEE Communications Magazine, 49(6), 26-30, (2011)

27. R. Edwards and E. Lynn. The Utilization of Amateur Radio in Disaster Communications. DIANE Publishing, (1994)

28. R.L. Mathew, J.E. Dolly. Information technology and public health management of disasters a model for South Asian countries. Prehospital and disaster medicine 20.01, 54-60(2005)

29. T.Schmitt, Rao, R. Ramesh and J. Eisenberg. Improving disaster management: the role of IT in mitigation, preparedness, response and recovery, National Academies Press, (2007)

30. Y. Irwandi.Mengenang Mangsa Bencana Gempa Bumi dan Tsunami di Aceh 26 Desember 2004. Indonesia, Provinsi NAD, (2009) 